\title{
The twenty-first century, the century of plant breeding
}

\section{Journal Article}

\section{Author(s):}

Stamp, Peter; Visser, Richard

Publication date:

2012-08

Permanent link:

https://doi.org/10.3929/ethz-b-000053863

Rights / license:

In Copyright - Non-Commercial Use Permitted

Originally published in:

Euphytica 186(3), https://doi.org/10.1007/s10681-012-0743-8 


\title{
The twenty-first century, the century of plant breeding
}

\author{
Peter Stamp $\cdot$ Richard Visser
}

Received: 12 April 2012/Accepted: 11 June 2012/Published online: 1 July 2012

(C) Springer Science+Business Media B.V. 2012

\begin{abstract}
To achieve global food security by 2050 primary production must almost be doubled, at least to $80 \%$ by increasing production per unit land. The challenge to plant breeding is tremendous. It is necessary to convince the public of this challenge, who are already dealing with concerns about climate change, a scarcity of good arable land, the demands placed on land with regard to biomass production, scarcity of water and phosphorous as well as increasing consumption of meat. In terms of breeding, concerns are the very small number of major crops and low rates of breeding progress in self-pollinating cereals. Society and politicians can be easily distracted from the dire need to invest in basic breeding research and breeding applications when so many environmental concerns are being emphasized. A holistic approach to these problems is essential. The focus here is on both the obstacles to be overcome and the opportunities to ensure global food security by producing excellent germplasm by 2050. This can be achieved by new technologies and genomics as well as
\end{abstract}

P. Stamp ( $\bowtie)$

Institute of Agricultural Sciences, ETH Zürich, Universitaetsstrasse 2, 8092 Zurich, Switzerland e-mail: peter.stamp@ipw.agrl.ethz.ch

\section{R. Visser}

Wageningen UR Plant Breeding, Wageningen University and Research Centre, Droevendaalsesteeg 1, 6708 PB,

Wageningen, The Netherlands the continuing development of more traditional breeding methodologies.

Keywords Breeding importance .

Global food security $\cdot$ New breeding tools

\section{Introduction}

Mankind began to cultivate crops 10,000 years ago in the Near East. Within a few thousand years, the cultivation of crops took hold almost simultaneously from China to Peru. These developments are generally thought to have occurred independently. However, knowledge may have been communicated by long distance travelers, too. Starting about 500 years ago, all major crops were exchanged between the Old and the New World and are now cultivated globally. The twentieth century was marked by steady scientific progress that included targeted breeding after the rediscovery of Mendel's laws as well as an amazingly swift implementation of crop physiology in crop management. Every step forward has contributed to an increase in the global population as starvation decreased. However, we have known for decades that the supply of food will become limited in the not too distant future. Breeding is the only way to slow down this progression. It will take time to achieve a balance between consumption and reliance on sustainable resources. 
To meet future demands by plant breeding the challenges must be understood in order to achieve food security by 2050 .

\section{Food security}

All conscientious agronomists must give top priority to Global Food Security. Together with biologists, geographers, ecologists and economists, agronomists must take responsibility for the long-term availability of resources, their interactions and the challenges with regard to maintaining fertile land and the continuous adaption of crops to all climatic conditions. Investment must be enforced in the education of highly trained agronomists, with a special focus on developing countries without strong extension services and breeding programs. When state or private breeding programs are already established, the efficient translation of progress in molecular science will be unduly delayed without more applied or practical plant breeders. Much has been written about global food security in the last two decades and the problems that must be overcome in the next few decades (Source: FAO 2009, 2010; World Bank 2009). Already in 2008 food prices began to increase, something that was not expected to happen before 2020. In 2011, another dramatic increase in food prices motivated the president of the World Bank to issue warnings that people in many parts of the world were being driven into extreme poverty (World Bank 2011).

Many constraints for food security have been intensively discussed in recent times, often in a rather disciplinary context. A reemerging one is the shocking speculation of primary agricultural products on the stock market. As again the poverty-stricken suffer most, a closer interaction between governments and the private sector is needed (Gilbert 2011).

\section{Constraint 1: climate change continues}

There have been incremental increases in $\mathrm{CO}_{2}$ and temperature for more than 100 years. Such slow changes can be dealt with indirectly by selecting new varieties in plant populations with broad genetic variability in target environments. Breeders now have the means to introgress genetic resources from regions with similar climatic conditions or to introduce new crops that grow well at higher temperatures (C4
Plants) or higher $\mathrm{CO}_{2}$ levels (C3 Plants). Patterns of flooding and droughts have already been variable in most climates. But regional patterns of temperature and rainfall may change even more drastically; in consequence abiotic stress may occur at unexpected stages of plant development, thus decreasing yield consistency (Kranjak-Berisavljevic et al. 2009; Lobell et al. 2011). The greatest risk comes from increasing energy in global weather that seems to lead to unpredictable rapid and large changes in temperature, rainfall, wind and hail. No mechanisms are known for achieving adaptation of productive plants to extreme long-term drought or flooding, as productive plants usually react slowly to minor stress situations with moderate fluctuations in yield. Tolerance to extreme drought is just found in some desert species, which survive months without water at the expense of growth potential. Possibly the shoot morphology of some crops has to be modified to achieve coping mechanisms in storms and when hail occurs. Gains in yield potential due to an increase in $\mathrm{CO}_{2}$ should not be missed by loss of green area and harvestable organs.

\section{Constraint 2: good arable land is becoming scarce}

There is considerable debate about the global availability of arable land. Throughout the twentieth century warnings about the scarcity of land have always been counterbalanced by large gains in yield. Some opinions are around that underused land reserves do exist and that just better governance is required. It may indeed be possible to improve productivity in some marginally used areas in Africa and South America. But long-term implications for ecology must be taken into account, as all the best fertile flat land has been under cultivation for a very long time. Some believe that climate change will just move the temperate cereal belt northwards to the vast Eurasian and Canadian boreal forest zones. However, most of those soils there are sandy podzols characterized by low yield consistency.

As a fact, we lose $70-140,000 \mathrm{~km}^{2} /$ year of farming land through soil erosion and other forms of land degradation (Sundquist 2010). Large areas are already infertile or less productive due to erosion and salinization (Pimentel 2006). This may be driven by largescale farming on former rainforest land as well as by increasing number of smallholdings on steep slopes in monsoon areas. As rapid and even more disastrous is 
the sealing of good agricultural land, a permanent loss. For economic reasons it is logical not to build factories, offices and roads on steep slopes instead of in flat valleys with cheap logistics. According to this rationale, about $50 \%$ of the best arable land has been sealed in the progress of economic development in Japan and South Korea during the last century, an ongoing process in China. In Europe or in Asia, cities and roads are always built on the best arable land. Therefore dramatic forecasts of future land scarcity must be taken very seriously as long as long as soilborne traditional crops have the dominant role in human nutrition.

Constraint 3: water and phosphorous will soon be scarce

"Poor access to reliable, safe and affordable water for food and livelihoods is a poverty trap for $70 \%$ of the world's poor people, i.e. the 800 million poor people that live in rural Africa and Asia." (Rijsberman and Manning 2006). Few regions in the world, especially in cool temperate and subtropical/tropical zones, have sufficient water to avoid plants being subjected to severe stress phases. In many important agricultural areas, variable patterns of rainfall jeopardize the successful cultivation of annual crops. Early leading civilizations recognized the necessity of irrigation for managing crops. Today the demand for water for producing food competes with other demands for water by the public and private industrial sectors, so that available water for irrigation will decrease (Pimentel et al. 2004). A major problem still exists in the fact that present models are much more accurate in predicting temperature changes than rainfall changes, therefore yield consistency will surely decline, but regional impacts remain obscure still (FAO 2011).

Phosphorous is essential for life as all chemical processes in the cell require energy transmission by ATP. About 50 years ago it was predicted that phosphorous reserves would last for five more centuries. This is no longer valid due to the demand for greater productivity; the scarcity of available phosphorous in old tropical soils means that readily available sources of phosphorous will last for just 50 years, a consequence of improved varieties and increased production potentials (Jansa et al. 2010; Lougheed 2011).New strategies are required to utilize phosphorous as a common good, including the control of phosphorous mining from the interior of continents to coastal cities, much of which ending up in the oceans.

Constraint 4: misuse of good arable soil for biofuel

In the "good old days", homes were heated by firewood from nearby forests. Today, energy requirements for heating, cars and industrial production have increased tremendously. In view of all global constraints, global food security cannot be achieved if 25 percent of the world's energy needs must be met by arable land (FAO Newsroom, 25 April 2006. FAO sees major shift to bioenergy). In the meantime detailed analyses have been presented that provide a much more realistic picture of the potentials and risks of using agricultural and forest land for bioenergy production (FAO 2010). The contribution of bioenergy production on volatile food prices has been acknowledged by now as well (Babcock and Fabiosa 2011). However, this discussion has increased awareness that new, efficient methods can be developed to use by-products such as straw, produced in abundance by high-yielding cereals. Breeding for the better energy conversion of straw or for energy crops on marginal land may ease the energy problems in some areas. However, care should be taken that both good arable land and dedicated breeders are dedicated to global food security.

Constraint 5: vegetarian spirit of the East is dwindling fast

Nutritionists have provided us with an understanding of our dietary requirements and the composition of our plant products is well characterized; therefore we could live theoretically on a purely vegetarian diet. But most people like meat. Cereals are well suited for monogastrics, including humans. For that reason a considerable amount of cereal crops is used to feed other monogastrics like pigs and chickens, at an increasing rate. Within the last 200 years the western Europeans and Americans could afford to regularly put meat on the table; this change in eating habits is occurring just now in populous threshold countries. Demand for feed grains may more than double between now and 2050; people in these countries will consume then as much meat and dairy as was 
consumed per person in the United States and Europe in 1966 (Babcock 2008). This is a very negative perspective as much more water in $\mathrm{m}^{3}$ (average) is needed for meat than for plant products per $\mathrm{kg}$ : beef $15 \mathrm{~m}^{3}$, chicken $6 \mathrm{~m}^{3}$, cereals $1.5 \mathrm{~m}^{3}$ (see: http:// www.lenntech.com/water-food-agriculture.htm).

\section{Plant breeding}

Modern crops produce huge yields every year with rare failures in some continents, almost a miracle, which society takes for granted. Wild plants must regularly produce offspring or they will disappear. Until about 120 years ago this was mandatory for cultivated cereals as well, whose seeds were rarely transported at distances more than a few kilometers. Since then cereals have been selected for agronomically favorable genes, enabling them to produce steadily yields above 6-10 t per ha rather than about $1 \mathrm{t}$ of yield at their places of origin, mandatory now for our food security. Regional failures or natural limitations in seed production are easily compensated by transport of seeds across the globe. This has given farmers greater choices as it is no longer necessary to multiply vigorous seeds at the site of cultivation. These choices are based on major global crops, which have first been cultivated at least 2000 years ago.

Some agronomists, who talk about "new" crops such as sugar beet or quality rapeseed, forget that their characteristic new quality traits were based on old, already existing crops. In our discussion of food safety and breeding, it is necessary to accept reality that new crop species will not be ready to largely contribute to commodity production soon. The 5,000 + cultivated species are our world heritage; globalization has brought most of them to near extinction.

The demands placed on breeding are considerable and depend on the requirements of society and the matching potentials of environments; they include quality and consistency of yield, minimum yield in marginal areas, improvement of neglected species, and efficient use of genetic resources.

\section{Constraint 6: economy of plant breeding}

Private breeders are the major players in the international seed business. The ten largest companies have a global share in seed sales of more than $60 \%$ (information by UNEP/GRID Arendal 2008), they only invest in the leading crops for economic reasons. But this leads to the question whoever else will be responsible to breed underutilized crops! Looking back to the "Year of Biodiversity" 2010, demands for increased biodiversity at the crop level will just remain hollow words under these circumstances. Presently only hybrid seeds provide a solid return on investment. As maize hybrids have been integrated successfully in all growing areas for maize more investments are attracted by an already dominating crop. Major small grain cereals like wheat are no longer interesting from an economic point of view when farmers use their own seeds from self-pollinating crops, a dangerous development. In richer countries attempts have been made to establish hybrid systems, based on male sterility and restorer genes in small grain cereals; this has been achieved already in rice but progress has been less striking in wheat as traditional homozygous wheat varieties exist already with a very high yield potential.

\section{Constraint 7: economy and food preferences}

It adds to risks in food security that the three globally dominating cereals wheat, maize and rice, the "Great Three", deliver more than $55 \%$ of the human calorie intake. They are produced on almost 5.5 million $\mathrm{km}^{2}$ worldwide, $40 \%$ of all arable land (see FAOSTAT/ production/crops and FAOSTAT/resources/land).This is driven by our interests in the developed world, reinforced by the great success of the first two CGIAR institutes CIMMYT and IRRI who based the Green Revolution on the "Great Three". This is not an excuse, consumers do prefer these crops if they are available. The great diversity of popular products that can be produced from bread wheat is tremendous, from hundreds of bread types and cakes to pasta. These preferences must be respected as part of our culture. On the positive side, the potentials to improve the "Great Three" and some other major crops are huge, as they have been already adapted to many climatic zones since long time. It is our responsibility to continuously maintain the vigor and health of all of them. The epidemic of wheat stem rust caused by race Ug99 was a warning, but the speed, with which CIMMYT' scientists responded was encouraging as evidenced by Norman Borlaug's Global Rust Initiative. 
How do we meet with these challenges?

Most experts are unanimous that cereal production must double by 2050 . Given the constraints discussed above, an increase of about $80 \%$ in yield per unit area is necessary. Throughout the twentieth century we witnessed an incredible increase in wheat yields, from little more than $1 \mathrm{t}$ per ha grain yield of wild cereal stands on the Golan Heights, to more than 10 today under good farming conditions. Several recent reviews have pointed out the lack of yield increase of farm yields in Europe (Brisson et al. 2010) and the United States (Graybosch and Peterson 2010). Possible genetic reasons may be that major target traits of the last century that have been fully exploited. This concerns in particular the harvest index (HI) related mainly to shorter stems, which has driven the Green Revolution. There are, of course, other reasons such as extension of production to less favorable environments, hot and dry weather spells due to climatic change and government regulations, which require more ecological production systems. The topic of breeding and cereal yield progress has been dealt with effectively in a 2010 review by two experts in wheat and maize breeding (Fischer and Edmeades 2010); it makes sobering reading. According to them annual breeding progress must increase by 2.5 the current rates if we are to meet the target of doubling yields by 2050. This means fewer than three full breeding cycles from crossing to the released variety. Some encouraging evidence is presented for a new breeding goal, greater light use efficiency (RUE) in the period leading up to flowering, because recent progress seems to be related to higher rates of photosynthesis before and around anthesis. Will the next breeding target be photosynthesis? This would be a delayed reward for all the dedicated scientists decades ago, who were unable to prove causal links between photosynthesis and yield. The approach may be complicated with regard to $\mathrm{C} 3$ plants as high temperature and drought increase photorespiration, whereas $\mathrm{CO}_{2}$ enrichment increases RUE. Therefore, no simple breeding tools are at our disposal yet to select for RUE directly (Reynolds et al. 2009). At a still theoretical level, the potential to increase the light use efficiency seems to be high (Zhu et al. 2010). The authors corroborate that the HI approach to cereal breeding has reached its limits, light absorption is almost optimum, but the conversion of absorbed light into biomass promises a potential increase of biomass of $200 \%$. This would, however, demand radical changes mechanisms of photosynthesis that have operated for billions of years. Therefore it cannot serve for medium term solutions of achieving tens of thousands of adapted cereal varieties by 2050 .

How can we speed up breeding progress?

In a simplified view farmers recognized the best varieties from generation to generation, summed up by Marcus Terentius Varro, first century BC: "To obtain the best seeds for the next generation, thresh the best ears separately". Today both science-based breeding methods and farmers' experience are combined in socalled "Participatory Breeding", a reconciliation of past and present competences to find solutions for the future. Since the rediscovery of Mendelian laws conventional breeding was optimized throughout the last century, without changing the principal methods. This started with statistical packages for discriminating between phenotype and genotype, based on the principles of population and quantitative genetics, followed by the integration of both with the availability of ever more efficient software. Field layouts and field technologies changed considerably, thus optimizing choice of locations, including winter nurseries for second generations, data collection and field machinery. All these tools as well as laboratory analyses, must be managed optimally in a modern breeding company; their optimization will be the backbone of success in this century, too. In addition, new molecular tools will greatly enhance the breeding process; they have to be integrated intelligently to faster meet the challenges to food security (Lusser et al. 2011).

Marker-assisted selection (MAS) as outlined above, is being implemented to assist breeders in achieving their goals as quickly as possible, revealing the best allele combinations, even for polygenic traits. The breakthrough is partly due to modern DNA-chip technology, by which thousands of markers can be analyzed economically in one step. Physiology and biochemistry are now understood at the genetic level, something crop physiologists with limited descriptive approaches could hardly have imagined a few decades ago. Some optimistic molecular biologists predict already phenotyping as the new bottleneck in breeding progress. Nonetheless, MAS will probably not replace 
field tests in different environments but will increase the speed and the accuracy, with which new varieties are obtained.

Sustainable long-term progress in breeding still demands sufficient genetic variability. We now understand the importance of genetic resources, large numbers of which are stored in gene banks, at least for the major crops. These reserves have hardly been touched, because breeders feared negative effects of diluting their assembly of valuable agronomic genes by landraces. At present we are on track to applying molecular and genomic tools as well as traditional geographic information (GIS) to identify the desired allelic combinations for targeted introgressions in advanced breeding germplasm. Hopefully, this will boost the efficient use of gene banks (European Academies Scientific Acdvisory Council (EASAC) (2011). Gene technology is an important component of molecular biology and, thus, another increasingly efficient tool for breeders to enhance breeding progress when genetic bottlenecks are encountered, including the efficient use of genetic resources without gene drag. Once available, it should become a part of the modern toolbox to breed the best varieties in the most efficient way, in cases were other tools deliver inferior progress. But especially in Europe, the abundance of food means that the public is critical of new technologies and does not readily accept them. They have to be won over, if we are to achieve global food security. We do not advocate the introduction of any new technology without the necessary regulations for the safety of the entire food and environmental systems. But it would be a criminal act not to test all new technologies as possible aids to ensure food security. Driven by this mission, CIMMYT and other CGIAR institutes are now strongly encouraging developing and threshold countries to make use of all available strategies for rapid breeding progress. Even the European Union is on track now to evaluate the potentials of new technologies as foot shortages loom in the future (Lusser et al. 2011). The combined implementation of all traditional and newly developed, well tested tools must be done now and not later. New software will be required to increase opportunities for developing the desired varieties for the target environments. In other words, we are entering the next generation of breeding: precision breeding. We must surpass the present outcome of one variety from 100,000 seeds to five good varieties from even fewer seeds the near future.

\section{Conclusions and outlook}

Without delay public and private forces must be harnessed to drive the pace of plant breeding. There are still far too many constraints for doubling primary production by 2050 . Some obstacles must be overcome by better global governance, including the conservation of good arable land for future generations. Other obstacles are more complex and range from longestablished nutritional preferences to climate change. As new, well-tested technologies emerge, especially molecular tools like MAS, plant breeding will become more precise at a fast rate. This should principally speedup breeding progress, starting with the more efficient use of genetic resources to a reduction of multi-location trials as genotypic selection improves in the near future. Gene technology can additionally solve problems related to quality and resistance within and across the species borders, crucial timesaving to maintain the vigor of global crops and to provide better starts for underutilized crops. But these ambitious goals will only be swiftly realized when young agronomists can be motivated to turn into practical plant breeders for the translation of scientific progress into attractive crop varieties. The role of international agricultural research institutes remains essential to maintain the respective training and the upgrading of adapted germplasm in developing countries to optimize the choice in crop varieties.

But we can hopefully count on future well educated generations of experts from widely different fields to tackle these problems, by combining and sharing their expertise, making use of our best tool, human intelligence. This might start with the efficient use of horizontal and vertical areas in periurban and urban agriculture and go on to new ways of microbial systems for primary product generation. Whatever comes: We require a strong breeding community as all organisms used by us, from microbes to higher plants, must to undergo continuous adaptation and optimization by selection.

\section{References}

Babcock BA (2008) Charting growth in food demand. Iowa Ag Rev 14(3):1-3. http://www.card.iastate.edu/iowa_ag_review/summer_ 08/IAR.pdf

Babcock BA, Fabiosa J F (2011) The impact of bioethanols and ethanol subsidies on corn prices: revisiting history. CARD 
Policy Brief, 11-PB 5. Iowa State University, Ames. .http:// www.card.iastate.edu/publications/dbs/pdffiles/11pb5.pdf

Brisson N, Gate P, Gouache D, Charmet G, Oury FX, Huard F (2010) Why are wheat yields stagnating in Europe? A comprehensive data analysis for France. Field Crop Res 119:201-212

European Academies Scientific Advisory Council (EASAC) (2011) Plant genetic resources for food and agriculture: roles and research priorities in the European Union. EASAC policy report 17. ISBN 978-3-8047-3017-5. http:// www.easac.eu/fileadmin/PDF_s/reports_statements/ Easac_12_PGR_complete_Web.pdf

FAO (2009) How to feed the world in 2050. Food and Agriculture Organization of the United Nations, Rome. http:// www.fao.org/fileadmin/templates/wsfs/docs/expert_ paper/How_to_Feed_the_World_in_2050.pdf

FAO (2010) Bioenergy and food security. The BEFS analytical framework. environment and natural resources management series no. 16. Food and Agriculture Organization of the United Nations, Rome. http://www.fao.org/docrep/ 013/i1968e/i1968e.pdf

FAO (2011) FAO Water Reports 36. Climate change, water and food security by Hugh Turral, Jacob Burke and Jean-Marc Faurès. Food and Agriculture Organization of the United Nations, Rome. ISBN 978-92-5-106795-6. http://www.fao. org/docrep/014/i2096e/i2096e.pdf

Fischer RA, Edmeades GO (2010) Breeding and cereal yield progress. Crop Sci 50:85-98

Gilbert CL (2011) Food reserves in developing countries: trade policy options for improved food security. ICTSD Programme Agricultural Trade and Sustainable Development. Issue Paper No. 37. International Centre for Trade and Sustainable Development, Geneva. http://ictsd.org/ downloads/2011/12/food-reserves-in-developingcountries.pdf

Graybosch RA, Peterson CJ (2010) Genetic improvement in winter wheat yields in the Great Plains of North America, 1959-2008. Crop Sci 50:1882-1890

Jansa J, Frossard E, Stamp P, Kreuzer M, Scholz RW (2010) Future food production as interplay of natural resources, technology and human society. J Ind Ecol 14:874-877

Kranjak-Berisavljevic G, Osman-Elasha B, Shah WP, Stone JMR (2009) Climate change. In: McIntyre BD, Herren HR, Wakhungu J, Watson RT (eds) Agriculture at a crossroads, IAASTD, synthesis report, Island Press, Washington DC. ISBN 978-1-59726-550-8

Lobell DB, Schlenker W, Costa-Robins J (2011) Climate trends and global crop production since 1980. Science 333: 616-620
Lougheed T (2011) Phosphorus paradox: scarcity and overabundance of a key nutrient. Environ Health Perspect 119(5):A209-A213

Lusser M, Parisi C, Plan D, Rodriguez E (2011) New plant breeding techniques. State-of-the-art and prospects for commercial development. EUR-Scientific and Technical Research series-ISBN 978-92-79-19715-4. http://ftp.jrc.es/ EURdoc/JRC63971.pdf

Pimentel D (2006) Soil Erosion: a food and environmental threat. Environ Dev Sustain 8:119-137

Pimentel D, Berger B, Filiberto D, Newton M, Wolfe B, Karabinakis E, Clark S, Poon E, Abbett E, Nandagopal S (2004) Water resources, agriculture and the environment. College of Agriculture and Life Sciences, Cornell University, Ithaca. http://ecommons.cornell.edu/bitstream/1813/352/ 1/pimentel_report_04-1.pdf

Reynolds M, Foulkes MJ, Slafer GA, Berry P, Parry MAJ, Snape JW, Angus WJ (2009) Raising yield potential in wheat. J Exp Bot 60:1899-1918

Rijsberman FR, Manning N (2006) Beyond more crop per drop. Water management for food and environment, 4th World Water Forum, 16-22. March, Mexico. http://www.unwater. org/downloads/Beyondmorecropperdrop.pdf

Soil and Water Conservation Society (SWCS) (2003) Conservation implications of climate change: soil erosion and runoff from cropland. Soil and Water Conservation Society, January 2003, Ankeny. http://www.swcs.org/ documents/filelibrary/advocacy_publications_before_ 2005/Climate_changefinal_112904154622.pdf

Sundquist B (2010) Topsoil loss-causes, effects, and implications: a global perspective. 9th edn, March 2011 (updated September 2011). http://home.windstream.net/bsundquist1

UNEP/GRID (2008). http://www.grida.no/graphicslib/detail/ projected-gains-losses-for-countries-under-doha-scenariofor-agriculture_ec84 (03 Jan 2008-by IAASTD/Ketill Berger, UNEP/GRID-Arendal)

World Bank (2009) World Development Report 2010: development and climate change ISBN: 978-0-8213-7987-5. (http://www-wds.worldbank.org/external/default/WDS ContentServer/IW3P/IB/2010/02/22/000334955_20100 222030300/Rendered/PDF/530770WDR02010101 Official0Use0Only1.pdf

World Bank (2011) World Bank Group President Robert B. Zoellick, Remarks at the Opening of the World Bank/IMF spring meetings April 14, 2011, Press Conference Washington DC. http://go.worldbank.org/GQ5QMIVQ10

Zhu XG, Long SP, Ort DR (2010) Improving photosynthetic efficiency for greater yield. Annu Rev Plant Biol 61:235-261 